\title{
HYPOSTHENURIA IN SICKLE CELL ANEMIA: A REVERSIBLE RENAL DEFECT
}

\author{
By H. G. KEITEL, D. THOMPSON, AND H. A. ITANO \\ (From the National Institutes of Health, Bethesda, Maryland, Freedman's Hospital, and the \\ Department of Pediatrics, Howard University, Washington, D. C.)
}

(Submitted for publication March 19, 1956; accepted May 11, 1956)

The frequent occurrence of hyposthenuria in patients with sickle cell anemia has been noted since 1928 (1). McCrory, Goren, and Cornfeld (2), and Kunz, Pratt, Mellin, and Cheung (3), established that the urinary concentration defect was not due to a deficiency of the antidiuretic hormone and Zarafonetis, Steiger, Molthan, McMaster, and Colville (4), reported that subjects with the sickle cell trait also had hyposthenuria.

It has been suggested that the renal defect has a genetic basis (4); however, the data to be presented demonstrate the correction of the concentration defect in sickle cell anemia patients in whom intravascular sickling was suppressed by transfusions of normal red blood cells.

\section{METHODS}

The concentration of solutes in urine was determined cryoscopically with the Bowman freezing point apparatus (5). The accuracy attained is within two per cent. The symbol mOsml. used to designate the solute concentration of urine, represents that concentration which results in a freezing point depression of $1.86 \times 10^{-30} \mathrm{C}$. and is equivalent to a solution containing one millimole of "ideal" solute per $1,000 \mathrm{gm}$. of water.

The bisulfite method was used for determining the presence of sickle cells (6). The method of Wells and Itano was used for the identification of hemoglobin (7), and the benzidine method, as modified by Crosby, Munn, and Furth was used for the plasma hemoglobin determination $(8)$.

\section{Urine concentration tests}

A. The routine concentration test: Unless otherwise indicated, the routine urine concentration test was used for the determination of the ability to concentrate urine. Ingestion of food and water was prohibited for 14 to 17 hours. The overnight urine was collected and discarded about 2 hours before the administration of Pitressin. Two units of Pitressine were administered subcutaneously at about the 15th hour of fasting and thirsting and another two units were administered 30 minutes later. Urine samples were collected 10,30 , and 60 minutes following the first injection of Pitressin. The most concentrated of the three samples was considered to repre- sent the maximal urine concentration ability under the conditions of the test. If successive urine samples showed any degree of progressive concentration, it was assumed the subject had ingested water and the test was repeated. A catheter was used to obtain urine from infants under 2 to 3 years of age and from the occasional adult who could not void. Some of the children cried following the parenteral medication; otherwise, the patients remained quiescent during the test.

In most cases the concentrations of the three urine samples were of the same order of magnitude. Occasionally the urine samples following the administration of Pitressin (1) were more dilute than the sample obtained before the Pitressin was administered; this observation was confined chiefly to the infants and children who physically manifested their displeasure at having received an injection. Possibly a renal hemodynamic change or solute diuresis resulted from the crying.

B. Simple dehydration test: This test was identical to test $\mathrm{A}$ above except that Pitressin was not used and the urine collections were extended for two one-hour periods.

C. Urine concentration test during water administration: The patient was urged to drink water to his maximum ability. While the patient was undergoing water diuresis and was in positive water balance amounting to about 2 to 3 per cent of body weight, Pitressin was administered and urine collected as in the routine urine concentration test described above.

\section{Case material}

The control subjects included normal volunteers, nonsicklemic siblings of patients with sickle cell anemia and genetic dwarfs.

The sickle cell anemia patients had a history of sickle cell crises and had been hospitalized frequently. Hematological examination revealed positive sickling, predominantly " $S$ " hemoglobin by paper electrophoresis and reticulocytosis (see Table I). Most of the older patients had received many transfusions but almost none of the patients under 3 years had been transfused. Several transfusions had been given to patients Nos. 25 and 26 within 5 months of the study. Patient No. 24 had thalassemia-sickle cell disease and patient No. 9 had sickle cell " $C$ " disease.

\section{RESULTS}

The urine concentration test was performed on 12 white and 12 nonsicklemic negro normal con- 
TABLE I

Sickle cell anemia patients

\begin{tabular}{|c|c|c|c|c|c|c|c|c|c|}
\hline \multirow[b]{2}{*}{ Pt. } & \multirow[b]{2}{*}{ Sex } & \multirow[b]{2}{*}{$\begin{array}{l}\text { Age } \\
\text { years }\end{array}$} & \multicolumn{2}{|c|}{ Whole blood } & \multicolumn{3}{|c|}{ Plasma } & \multirow[b]{2}{*}{ 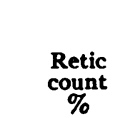 } & \multirow[b]{2}{*}{$\begin{array}{l}\text { Urine } \\
\text { conc. test } \\
\text { mOsml. }\end{array}$} \\
\hline & & & $\underset{G m . \%}{\text { Hb }}$ & $\underset{\%}{\text { Hct. }}$ & $\mathbf{H b}$ & $\underset{m g . \%}{\text { Bubili- }}$ & Urea & & \\
\hline $\begin{array}{r}1 \\
2 \\
3 \\
4 \\
5 \\
6 \\
7 \\
8 \\
9 \\
10 \\
11 \\
12 \\
13 \\
14 \\
15 \\
16 \\
17 \\
18 \\
19 \\
20 \\
21 \\
22 \\
23 \\
24 \\
25 \\
26 \\
27 \\
28 \\
29\end{array}$ & $\begin{array}{l}\mathbf{F} \\
\mathbf{F} \\
\mathbf{F} \\
\mathbf{M} \\
\mathbf{F} \\
\mathbf{M} \\
\mathbf{F} \\
\mathbf{M} \\
\mathbf{F} \\
\mathbf{F} \\
\mathbf{M} \\
\mathbf{M} \\
\mathbf{F} \\
\mathbf{M} \\
\mathbf{M} \\
\mathbf{M} \\
\mathbf{M} \\
\mathbf{F} \\
\mathbf{F} \\
\mathbf{M} \\
\mathbf{F} \\
\mathbf{M} \\
\mathbf{M} \\
\mathbf{F} \\
\mathbf{M} \\
\mathbf{F} \\
\mathbf{F} \\
\mathbf{F}\end{array}$ & $\begin{array}{c}9 \\
91 \\
1 \\
2 \\
23 \\
3 \\
3 \\
3 \\
4 \\
4 \\
4 \\
5 \\
6 \\
6 \\
6 \\
6 \\
8 \\
9 \\
9 \\
10 \\
12 \\
19 \\
19 \\
19 \\
23 \\
23 \\
24 \\
31 \\
41\end{array}$ & $\begin{array}{l}7.8 \\
\\
7.0 \\
7.8 \\
7.0\end{array}$ & $\begin{array}{l}25 \\
27 \\
22 \\
21 \\
25 \\
31 \\
20 \\
22 \\
\\
23 \\
28 \\
36 \\
22 \\
29 \\
23 \\
27\end{array}$ & $\begin{array}{c}26 \\
3.2 \\
19 \\
25 \\
24 \\
4 \\
24 \\
26 \\
\\
\\
15 \\
23 \\
5 \\
21 \\
13 \\
15 \\
3.5 \\
21 \\
4\end{array}$ & $\begin{array}{l}0.8 \\
0.3 \\
1.7 \\
2.5 \\
1.0 \\
1.2 \\
1.2 \\
0.6 \\
2.2 \\
1.0 \\
0.9 \\
3.3 \\
1.8 \\
1.1 \\
2.1 \\
3.0 \\
3.8 \\
\\
2.0 \\
3.1 \\
0.5 \\
5.0 \\
3.9 \\
1.3 \\
1.9 \\
3.0 \\
0.7 \\
2.5\end{array}$ & $\begin{array}{r}8 \\
10 \\
10 \\
14 \\
6 \\
7 \\
12 \\
13 \\
11 \\
9 \\
15\end{array}$ & $\begin{array}{r}11.5 \\
2.6 \\
21.4 \\
14.7 \\
13.0 \\
12.2 \\
\\
5.6 \\
5.8 \\
11 \\
12 \\
8.8 \\
13.8 \\
10.5 \\
\\
15.0 \\
5.9 \\
1.8 \\
7.0 \\
5.0 \\
4.5 \\
3.2 \\
5.0 \\
10.0 \\
10.0 \\
6.0\end{array}$ & 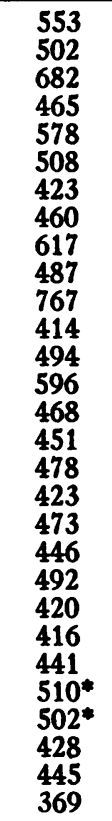 \\
\hline
\end{tabular}

* Blood transfusions had been given within 6 months.

trols of varying ages (see Figure 1A). The average urine concentration was similar in both groups of control subjects, and in subjects of different ages. The mean value and standard deviation for the 24 control subjects was $1,055 \pm 118 \mathrm{mOsml}$.

The urine concentration test was performed on 29 patients with sickle cell anemia (see Table I and Figure 1C). None of the patients was able to concentrate urine normally. No untransfused patient over 7 years of age achieved a concentration over $500 \mathrm{mOsml}$., whereas one-half of the patients under 7 years concentrated above $500 \mathrm{mOsml}$. One untransfused patient aged 4 years was able to concentrate to $767 \mathrm{mOsml}$. The blood urea nitrogen and routine urinalyses were normal in all patients.

It seemed reasonable to hypothesize that if the concentration defect were due to intravascular sickling or to sickle cell hemoglobinemia that the defect might be reversible if sickle cells were eliminated from the vascular system. Therefore multiple blood transfusions were given to seven patients.
The results of urine concentration studies of four children under five years of age with sickle cell anemia who were given multiple transfusions of normal red blood cells ${ }^{1}$ are presented in Figure 2. The maximum ability to concentrate urine increased from 553 to $682 \mathrm{mOsml}$. before the transfusions to 942 to $1042 \mathrm{mOsml}$. following the transfusions. The ability to concentrate urine returned to the pretransfusion level following cessation of transfusions and the return to the sicklemic state. As there was no decrease in the rate of excretion of solutes, the observed changes were not due to solute diuresis effect.

1 Blood stored from one to three days, from which 80 per cent of the plasma was removed, was used for the transfusions. The details concerning the per cent sickle cells remaining in the vascular system during multiple transfusions appear elsewhere (9). Less than 1 per cent sickle cells were seen when the whole blood hemoglobin concentration was maintained at 13 to $15 \mathrm{gm}$. per cent. However, the bone marrow continues to contain a normal number of sickle cells. When the hemoglobin concentration drops below $11 \mathrm{gm}$. per cent, reticulocytes and sickle cells reappear. 


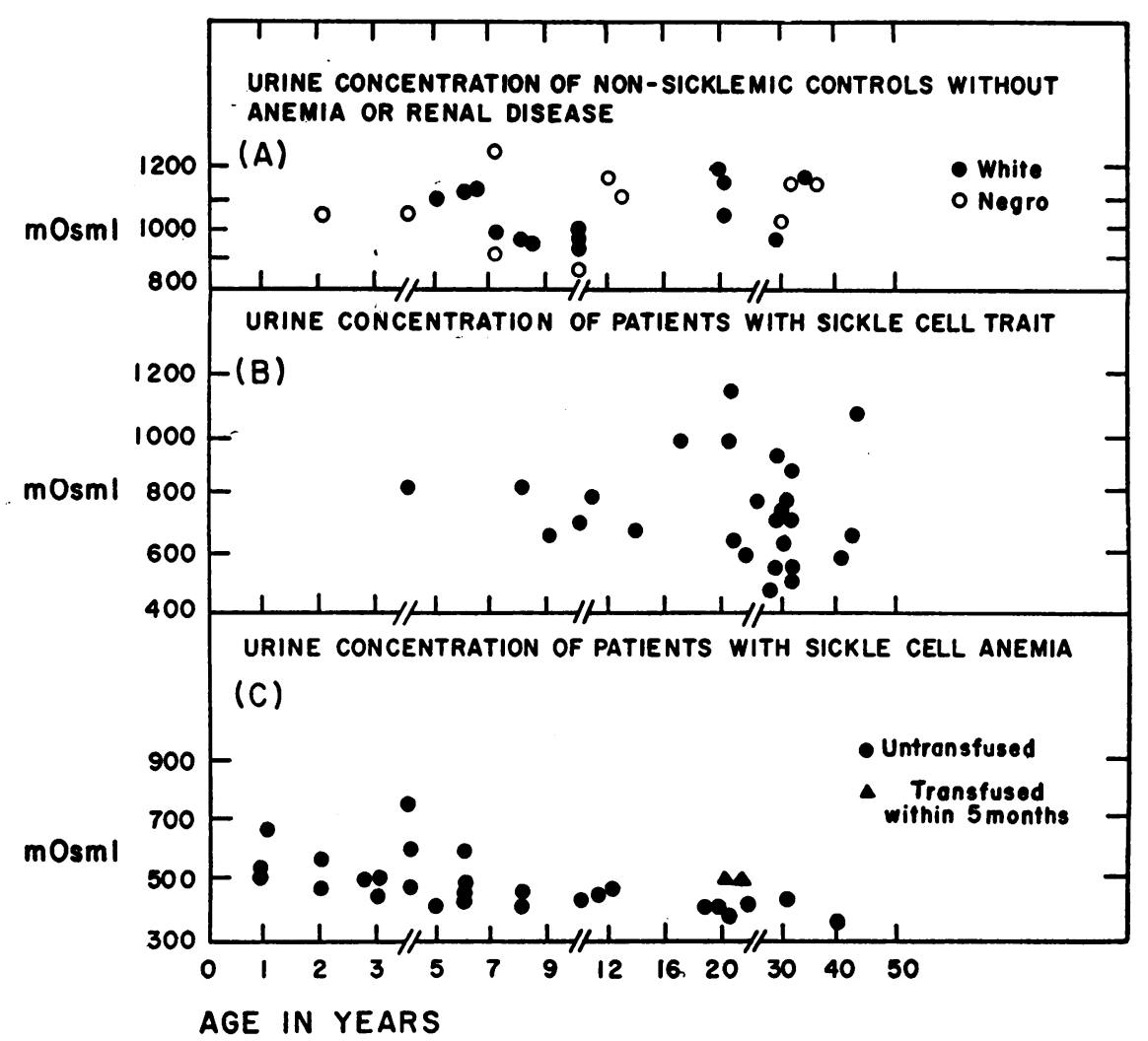

Fig. 1. The Maximum Solute Concentration of Urine at Different Ages in (A), Control Subjects (B), Sickle Cell Trait Subjects, and (C), Sickle Cell Anemia Patients

In a 10-year-old patient the maximum ability to concentrate urine increased from $500 \mathrm{mOsml}$. to $750 \mathrm{mOsml}$. only after 2 months of repetitive transfusions (see Figure 3). While this increase represents a substantial improvement in urine concentration, the highest concentration achieved is considerably below the lower limit attained by the control subjects. Possibly a normal maximum urine concentration would have been attained if the transfusions had been continued for a longer period. In two young adults the concentration defect was altered only slightly, or not at all, following correction of the anemia (see Figure 4). However, insufficient observations were made, and the transfusions may not have been continued for a sufficiently long period of time, to conclude that the urine concentration defect in these older patients was irreversible. The data suggest however that both the severity and reversibility of the hyposthenuria are altered with age.
A consideration of possible mechanisms resulting in hyposthenuria in sickle cell anemia

A. The possible effect of anemia and hemoglobinemia on formation of concentrated urine. It has been suggested that anemia, which in some instances is associated with reduced renal clearances of inulin and PAH (10), may result in hyposthenuria but this apparently is not always the case $(3,4,11)$. The maximum urine specific gravity value recorded in the hospital record of patients with various types of anemia, including some with chronic anemia, is seen in Figure 5. In over onethird of the patients specific gravity values over 1.025 were observed, whereas adult patients with sickle cell anemia have urine specific gravity values that range from 1.010 to 1.020 . The simple dehydration urine concentration test was performed on six adult patients with anemia not due to sickle cell disease. The results are presented in Table II. Normal urine solute concentrations were seen 
in four patients and a slightly reduced value was seen in one other. The value of $685 \mathrm{mOsml}$. of patient "G", the sixth patient, is higher than those observed in all but one of the sickle cell anemia patients. The patient with homozygous " $\mathrm{C}$ " disease, who obviously had the disorder since birth, had a higher plasma hemoglobin concentration than many of the sickle cell anemia patients.

Sickle cell anemia patient No. 21 had been noted to have hematocrit values above 35 per cent over a one-year period; the impairment of his urinary concentration ability is as severe as in the patients with a more pronounced degree of anemia. Several sickle cell anemia patients (Nos. 1, 5, 10, 14, 21 , and 28) have plasma hemoglobin concentrations which are just above the normal range (see Table I). In two of these patients (Nos. 1 and 27 ) it was ascertained that the plasma hemoglobin
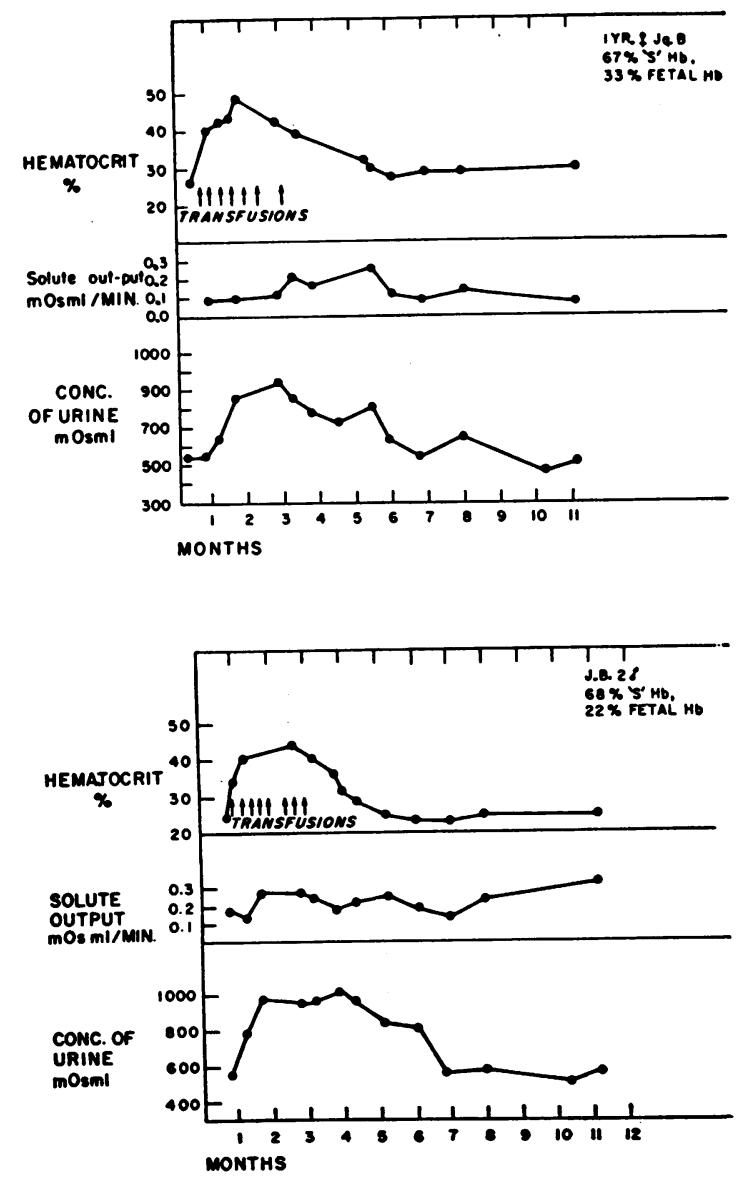

remained below $6 \mathrm{mg}$. per cent for several months, even during sickle cell crises. The urine concentration defect is as severe in these patients as in the patients with more pronounced hemoglobinemia. Since it has been shown that the degree of hemoglobinuria is usually directly related to the plasma hemoglobin concentration it would appear that hemoglobinuria also may not be the cause of the hyposthenuria.

B. Hemodynamic factors and renal function. A frequent finding in children with sickle cell anemia is an increase in the glomerular filtration rate (GFR) (12). However, adults with sickle cell anemia usually have a normal or even decreased GFR (13). It is not clear how an increase in the GFR could, in the absence of solute diuresis, influence the concentration of urine during hydropenia. The findings of Bruck (14) of an increase in the
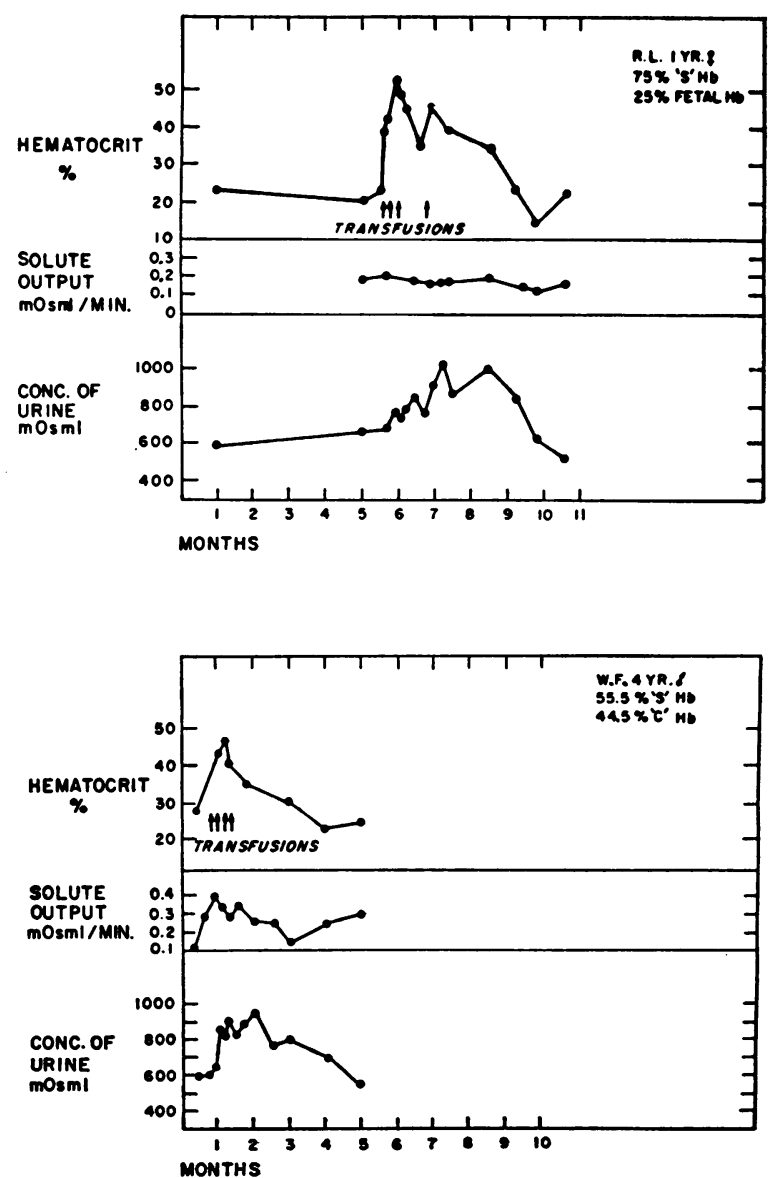

Fig. 2. The Maximum Solute Concentration of Urine in Three Children with Sickle Cell Anemia, and One Child with Sickle Cell Hemoglobin C Disease Following Multiple Transfusion of Normal Red BLOOD CELLS 


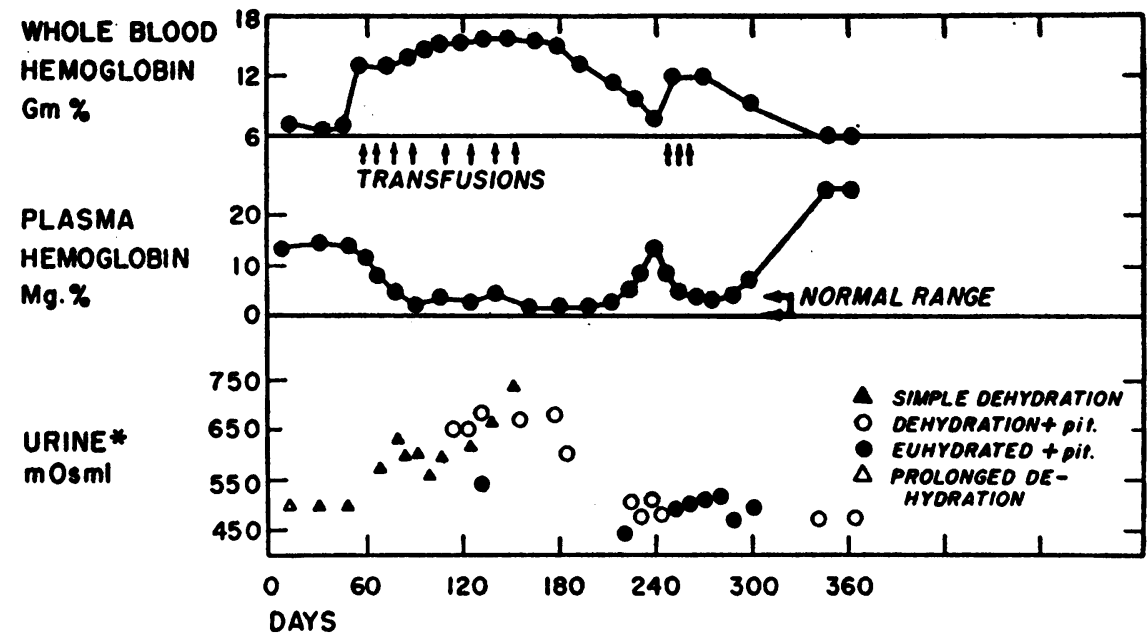

* THE MAXIMUM URINE CONCENTRATION OBTAINED FOLlOWING A STANDARD TEST. NO FOOD OR WATER INTAKE FOR 14 HOURS

Fig. 3. The Maximum Solute Concentration of Urine in a 10-Year Old Female with Sickle Cell Anemia following Multiple Transfusions of Red Blood Cells

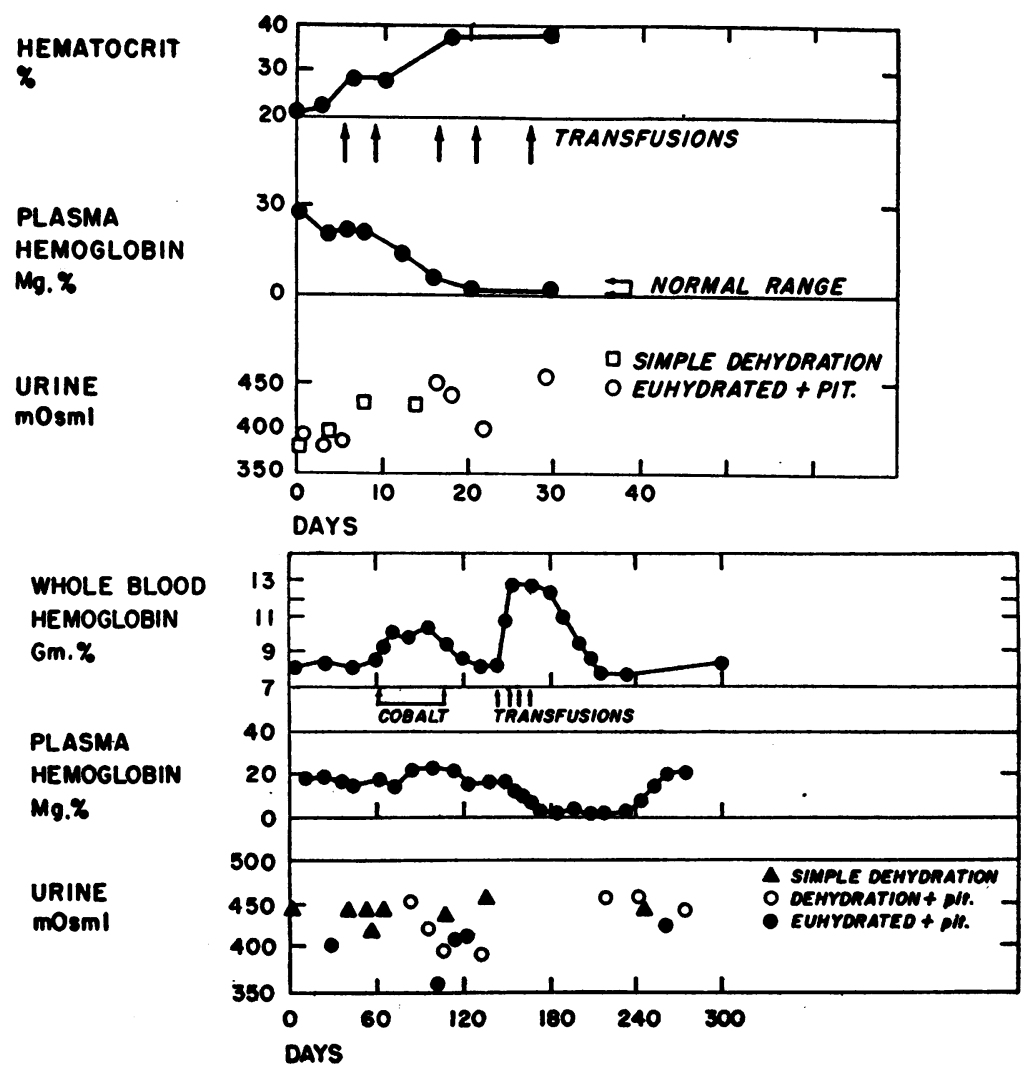

Fig. 4. The Maximum Solute Concentration of Urine in Two Adults with Sickle Cell Anemia following Transfusions of Normal Red Blood Cells and Cobalt Medication 


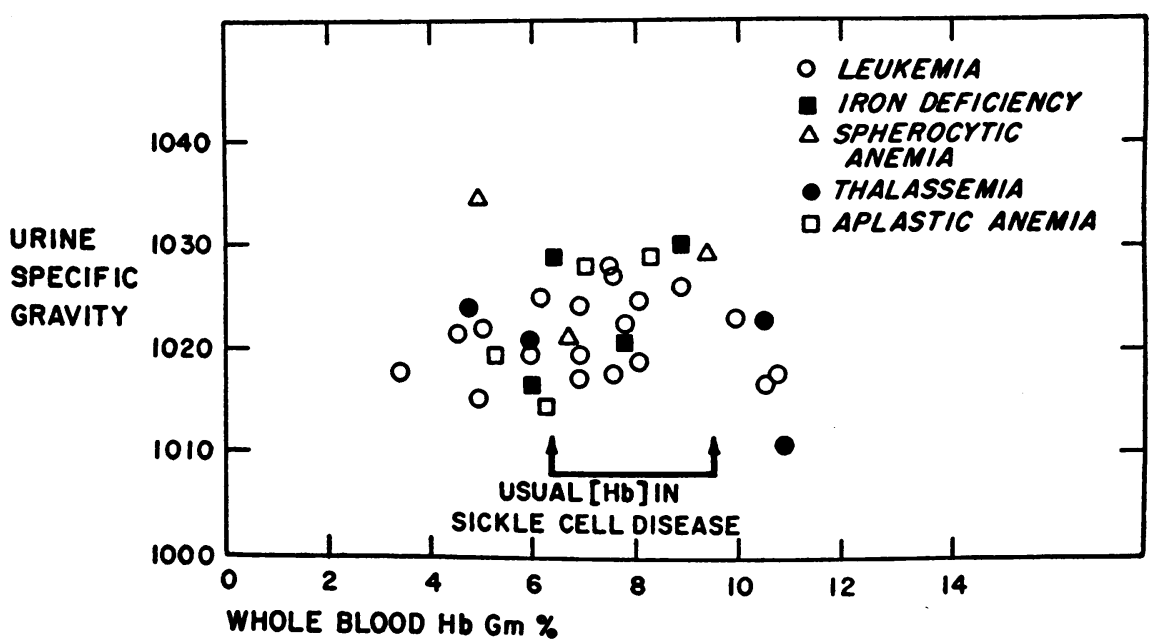

Fig. 5. The Urine Specific Gravity of Morning Fasting Urine in Patients with Anemia Nor Due to Sickle Cell Disease

GFR in patients with Mediterranean anemia indicate that the increase in GFR is not primarily related to the concentration defect since these patients concentrate normally (14).

Quiet standing, which resulted in syncope, and prolonged dehydration, which increased osmolality of plasma by 10 per cent, failed in each instance to alter the ability of the kidney to concentrate urine in two sickle cell anemia patients. Dehydration and quiet standing are frequently accompanied by a reduction in the GFR $(15,16)$.

The effect of correcting anemia on renal clearances was determined in two sickle cell anemia patients. The results which appear in Table III indicate no consistent change and confirm the observations of Bruck (14). It is clear, however, that the number of red blood cells flowing through the kidney per unit of time increased markedly following the correction of the anemia since the he- matocrit was increased two-fold. However, there is little reason to believe that a disturbance in oxygenation of renal cells is related to the concentration defect. The effect of 100 per cent oxygen administration for two hours on the urine concentration of solutes was observed in two waterdeprived patients with sickle cell anemia. The solute concentration of urine remained unchanged.

The urine concentration ability of subjects with the sickle cell trait

It has been suggested that the urine concentration defect in sickle cell anemia is genetic since the defect is also found in non-anemic trait parents of these patients (4). Table IV and Figure 1B indicate the results of urine concentration tests performed on 26 sickle cell trait subjects. With only two exceptions (cases Nos. 10 and 12) the subjects over 20 years of age are parents of sickle cell

TABLE II

The urine solute concentration in patients with anemia not due to sickle cell anemia

\begin{tabular}{|c|c|c|c|c|c|}
\hline Patient & $\begin{array}{l}\text { Hb. Gm. \% } \\
\text { and range }\end{array}$ & $\begin{array}{l}\text { Urine } \\
\text { mOsml. }\end{array}$ & $\begin{array}{l}\text { Hb. plasma } \\
\text { mg. \% }\end{array}$ & Diagnosis & $\begin{array}{c}\text { Duration } \\
\text { years }\end{array}$ \\
\hline $\mathbf{S}$ & \multirow{5}{*}{$\begin{array}{c}9 \\
(6-10) \\
8.5 \\
(7-10) \\
9 \\
(7-11) \\
9 \\
(8-10) \\
10.5 \\
7.6\end{array}$} & 957 & & Aplastic anemia & $\frac{1}{2}$ \\
\hline $\mathrm{Cr}$ & & 814 & & Chronic hemolytic anemia & 2 \\
\hline G & & 685 & & Chronic hemolytic anemia & 1 \\
\hline $\mathrm{Sr}$ & & 1,100 & $50-200$ & Chronic hemolytic anemia & 1 \\
\hline $\mathbf{S i}$ & & $\begin{array}{r}1,018 \\
863\end{array}$ & $\begin{array}{r}5 \\
15\end{array}$ & $\begin{array}{l}\text { Thalassemia minor } \\
\text { Homozygous hemoglobin " } C \text { " disease }\end{array}$ & $\begin{array}{l}39 \\
26\end{array}$ \\
\hline
\end{tabular}


TABLE III

Renal clearances in sickle cell anemia: Effect of transfusions

\begin{tabular}{|c|c|c|c|c|c|c|c|}
\hline \multirow{2}{*}{\multicolumn{2}{|c|}{ Patient }} & \multirow{2}{*}{$\underset{\%}{\text { Hct. }}$} & GFR & RPF & \multirow{2}{*}{$\begin{array}{l}\text { Tm PAH } \\
m g . / m i n . / 1.73 M^{2}\end{array}$} & \multirow[b]{2}{*}{ F.F. } & \multirow{2}{*}{ GFR/ $/ \mathrm{Tm} \mathrm{PAH}$} \\
\hline & & & $c c . / m$ & $1.73 \mathrm{M}^{2}$ & & & \\
\hline \multirow{2}{*}{$\begin{array}{l}\text { V. M. } \\
9 \text { years } \\
\text { Female }\end{array}$} & Before & 20 & 148 & 788 & 124 & 0.19 & 1.2 \\
\hline & After & 39 & 166 & 1,005 & 140 & 0.17 & 1.2 \\
\hline \multirow{2}{*}{$\begin{array}{l}\text { N. S. } \\
19 \text { years } \\
\text { Male }\end{array}$} & Before & 30 & 157 & 962 & 119 & 0.16 & 1.3 \\
\hline & After & 40 & 137 & 785 & 121 & 0.17 & 1.1 \\
\hline
\end{tabular}

disease patients. Only eight subjects with sickle cell trait achieved a urine concentration which was in the 95 percentile range of normal. The remaining 18 subjects had urine concentration maxima that are in the range described by the sickle cell anemia paients. A history of a G.U. tract infection was denied by all subjects except on No. 14. The plasma urea nitrogen concentration, routine urinalysis, plasma hemoglobin concentration and blood pressure were normal in all subjects in whom these tests were performed.

The GFR has been reported to be normal in the sickle cell trait $(17,18)$. This further indicates that the concentration defect is not a consequence of a hemodynamic change, if one assumes that the etiology of the concentration defect in both the trait and the sickle cell anemia patients is the same.

\section{The effect of Pitressin during water diuresis in sickle cell anemia and in normal controls}

Two normal subjects and two patients with sickle cell anemia were given graded doses of Pitressin intravenously during sustained water

TABLE IV

Sickle cell trait subjects

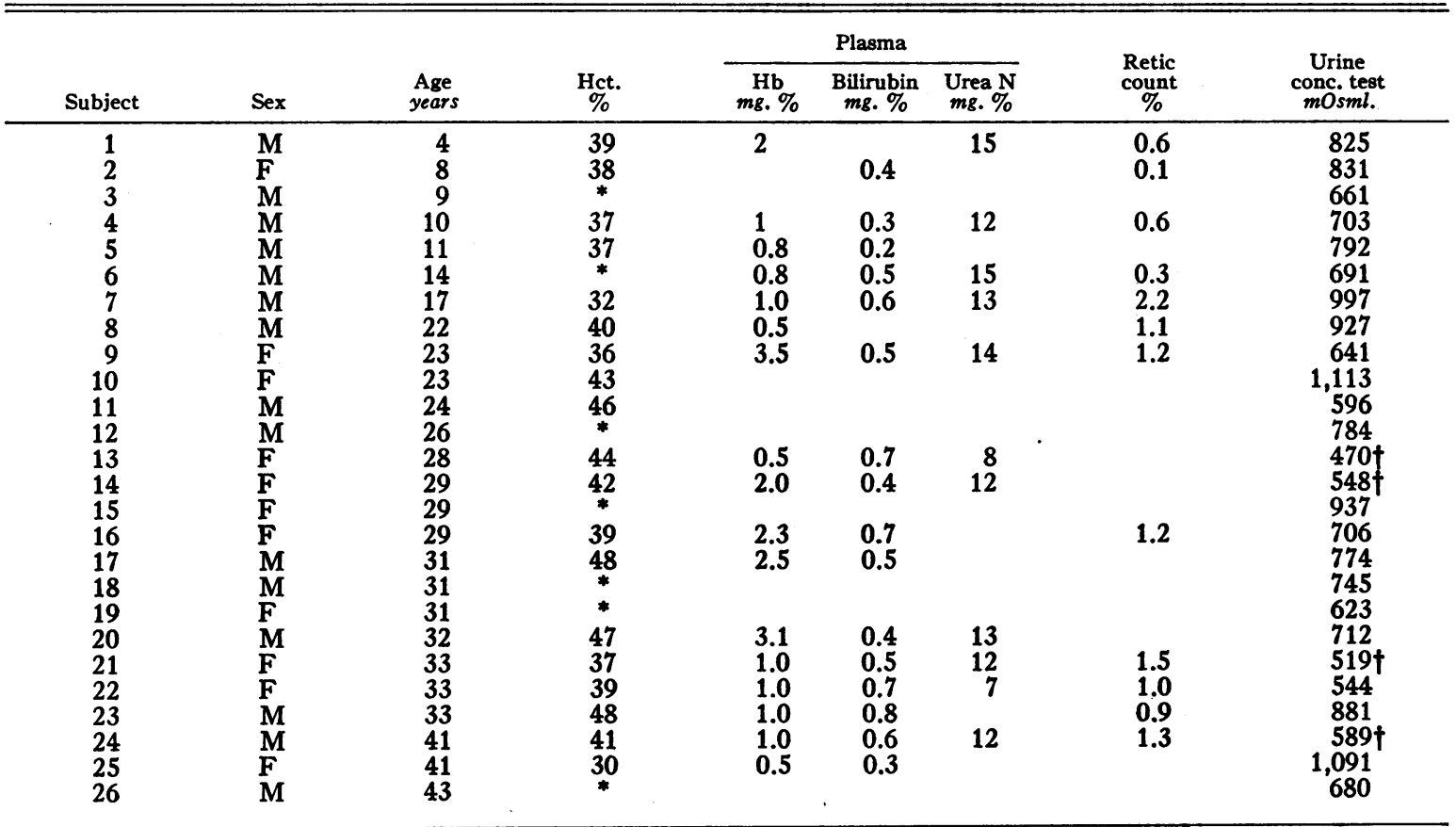

* In seven subjects $(3,6,12,13,15,19,26)$ whole blood hemoglobin values were reported to be normal within one year of the urine concentration study.

t Intravenous pyelogram normal. 
diuresis. The Pitressin ${ }^{-1}$ was taken from the same lot. In all 4 subjects 0.5 milliunits of Pitressin failed to alter the water diuresis, while 2.5 milliunits resulted in a cessation of maximum diuresis and an increase in osmolality of urine (see Table V). It would appear inappropriate to label the concentration defect in sickle cell anemia as being Pitressin ${ }^{\circledR}$-resistant, as suggested earlier (2). This is a term which might best be reserved for the condition characterized by the resistance to Pitres$\sin$ while the kidney is forming hypotonic urine.

\section{DISCUSSION}

In face of the finding that in young patients the urine concentration defect in sickle cell anemia was completely corrected following the elimination of sicklemia, there seems to be no reasonable alternative to concluding that the urine concentration defect results from the presence of sickle cell hemoglobin. It obviously is not due to extensive renal disease since the GFR, PAH clearance (1213), water diuresis and other renal functions (18) are often normal or supernormal. The finding that sickle cell trait subjects also exhibit the urine concentration defect indicates that the defect is not primarily due to anemia, if one assumes that the etiology of the concentration defect in these subjects is the same as in the sickle cell anemia patients. The presence of the defect in sickle cell anemia patients with only mild anemia further indicates that anemia is not primarily responsible for the renal defect.

Two possible mechanisms which might cause the defect in both the trait and anemia patients are
1) subclinical intravascular sickling in kidney and 2) a functional impairment of the concentrating mechanism due to the presence in the renal tubules or tubular cells of sickle cell hemoglobin.

Abel and Brown, and others (19-22) have reported the occurrence in sickle cell trait patients of tissue damage presumably resulting from intravascular sickling. In some cases high altitude flying precipitated sickle cell crises but usually no known predisposing circumstances favored intravascular sickling. Painless unilateral hematuria has been the most frequently reported abnormality in the sickle cell trait $(19,22)$. As the red cell survival time, reticulocyte count and plasma hemoglobin concentration are normal in the sickle cell trait it is quite certain that generalized intravascular hemolysis and an increased rate of red cell destruction do not usually occur (23-25). If sickle cell hemoglobin, as normal hemoglobin, is reabsorbed by the renal tubular cells from tubular urine (26-27), the presence of sickle cell hemoglobin may in some unexplained manner result in renal damage. However, the lowest concentration of " $\mathrm{S}$ " hemoglobin that can produce aggregation at zero oxygen tension and a $\mathrm{pH}$ of about 7 is between 7 and $10 \mathrm{Gm}$. per cent (28); therefore it would appear unlikely that renal intracellular precipitation of " $\mathrm{S}$ " hemoglobin occurs.

There is indication that severe chronic hemoglobinuria is deleterious to kidney function since only one of five of Ham's patients with chronic hemolytic anemia not due to sickle cell disease could concentrate urine normally; two of his patients had other signs of renal impairment (29). However, these patients had hemoglobinemia of

TABLE V

The effect of the intravenous administration of varying amounts of Pitressin (a) on the urine solute concentration and on urine flow during water diuresis in sickle cell anemia and in normal controls

\begin{tabular}{|c|c|c|c|c|c|c|c|c|c|c|c|c|c|}
\hline \multirow[b]{2}{*}{$\begin{array}{l}\text { Milli-units } \\
\text { of Pitressin (\$) } \\
\text { given I.V. }\end{array}$} & & 25 & 2.5 & 1.5 & 0.5 & 25 & 2.5 & 1.5 & 0.5 & 25 & 2.5 & 1.5 & 0.5 \\
\hline & & \multicolumn{4}{|c|}{$\begin{array}{c}\text { Duration of anti-diuresis } \\
\text { minutes }\end{array}$} & \multicolumn{4}{|c|}{$\begin{array}{l}\text { Pre-Pitressin @ } \\
\text { urine concentration } \\
\text { mOsml. }\end{array}$} & \multicolumn{4}{|c|}{$\begin{array}{l}\text { Maximal urine concentration } \\
\text { following Pitressin (i) } \\
\text { mOsml. }\end{array}$} \\
\hline \multirow{2}{*}{$\begin{array}{l}\text { Sickle cell } \\
\text { anemia } \\
\text { patients }\end{array}$} & N.S. & 105 & 75 & & 0 & 28 & 92 & & 34 & 302 & 367 & & 29 \\
\hline & V. M. & 95 & 75 & 55 & 0 & 45 & 60 & 41 & 36 & 508 & 375 & 169 & 36 \\
\hline \multirow{2}{*}{$\begin{array}{l}\text { Normal } \\
\text { controls* }\end{array}$} & H. & 75 & 95 & 45 & 0 & 50 & 55 & 50 & 43 & 739 & 835 & 90 & 37 \\
\hline & S. & 90 & 90 & 45 & 0 & 107 & 53 & 47 & 97 & 745 & 845 & 65 & 80 \\
\hline
\end{tabular}

* Normal hospitalized volunteers. 
much greater severity than any of our sickle cell anemia patients.

\section{SUMMARY}

1. Impairment of urine concentration was seen in 29 patients with sickle cell anemia, sickle cell "C" disease and sickle cell thalassemia. The concentration defect was not associated with other evidence of renal impairment.

2. The ability to concentrate urine was restored to normal in four infants with sickle cell disease following multiple transfusions of normal red blood cells. In a 10-year-old child the concentration defect was only slowly and incompletely corrected and in two young adults little or no change in concentration ability was observed following multiple transfusions.

3. The minimal threshold response to Pitressin ${ }^{\circ}$ during water diuresis appears to be normal in sickle cell anemia.

4. The possibility that the urine concentration defect in sickle cell anemia and the sickle cell trait results from renal damage due to either intravascular sickling or from the presence of sickle cell hemoglobin in renal tubular cells is discussed.

5. Impairment of urine concentration was seen in 69 per cent of subjects with the sickle cell trait. In most instances the degree of impairment was less than that seen in patients with sickle cell anemia. Other evidence of renal damage was lacking.

6. Hyposthenuria is the most common complication associated with the presence of intravascular "S" hemoglobin.

\section{ACKNOWLEDGMENTS}

The authors appreciate the opportunity to thank the following people for their generous advice, support and referral of patients: Dr. R. W. Berliner, National Heart Institute, Bethesda, Maryland, Dr. Roland Scott and Dr. Melvin Jenkins, Department of Pediatrics, Howard University, Washington, D. C., Dr. W. Bullock, Department of Medicine, Howard University, Washington, D. C., Dr. W. Crosby, Walter Reed Army Medical Center, Washington, D. C., Dr. Charles Rath, Department of Medicine, Georgetown University, Washington, D. C., Miss Mollie A. Golden, nurse in the O.P.D. of the National Institutes of Health, and Dr. M. Halperin, National Institutes of Health, who provided assistance in the statistical analysis of the data.

\section{REFERENCES}

1. Josephs, $H$., Clinical aspects of sickle cell anemia. Bull. Johns Hopkins Hosp., 1928, 43, 397.

2. McCrory, W. W., Goren, N., and Cornfeld, D., Demonstration of impairment of urinary concentration ability or "Pitressin-resistance" in children with sickle-cell anemia. Am. J. Dis. Child., 1953, 86, 512.

3. Kunz, H. W., Pratt, E. L., Mellin, G. W., and Cheung, M. W., Impairment of urinary concentration in sickle cell anemia. Pediatrics, 1954, 13, 352.

4. Zarafonetis, C. J. D., Steiger, W. A., Molthan, L., McMaster, J., and Colville, V. F., Renal defect associated with sickle cell trait and sickle cell disease. J. Lab. \& Clin. Med., 1954, 44, 959.

5. Bowman, R. L., Trantham, H. V., and Caulfield, $P$. A., An instrument and method for rapid, dependable determination of freezing-point depression. J. Lab. \& Clin. Med., 1954, 43, 310.

6. Daland, G. A., and Castle, W. B., A simple and rapid method for demonstrating sickling of the red blood cells: The use of reducing agents. J. Lab. \& Clin. Med., 1948, 33, 1082.

7. Wells, I. C., and Itano, H. A., Ratio of sickle-cell anemia hemoglobin to normal hemoglobin in sicklemics. J. Biol. Chem., 1951, 188, 65.

8. Crosby, W. H., Munn, J. I., and Furth, F. W., Standardizing a method for clinical hemoglobinometry. U. S. Armed Forces Med. J., 1954, 5, 693.

9. Chaplin, H., Keitel, H. G., and Peterson, R. E., Hematological observations on sickle cell anemia patients sustained at normal hemoglobin levels by multiple transfusions. Blood, In press.

10. Bradley, S. E., and Bradley, G. P., Renal function during chronic anemia in man. Blood, 1947, 2, 192.

11. Hayman, J. M., Jr., Shumway, N. P., Dumke, P., and Miller, M., Experimental hyposthenuria. J. Clin. Invest., 1939, 18, 195.

12. Etteldorf, J. N., Tuttle, A. H., and Clayton, G. W., Renal function studies in pediatrics. I. Renal hemodynamics in children with sickle cell anemia. Am. J. Dis. Child., 1952, 83, 185.

13. Etteldorf, J. N., Smith, J. D., Tuttle, A. H., and Diggs, L. W., Renal hemodynamic studies in adults with sickle cell anemia. Am. J. Med., 1955, 18, 243.

14. Bruck, E., Renal function in anemia. Am. J. Dis. Child., 1953, 86, 511.

15. Brun, C., Knudsen, E. O. E., and Raaschou, F., On the cause of postsyncopal oliguria. Acta med. Scandinav., 1945, 122, 486.

16. Young, W. F., and McCance, R. A., The secretion of urine by dehydrated and normal infants. Arch. Dis. Childhood, 1942, 17, 65.

17. Calcagno, P. L., McLavy, J., and Kelley, T., Glomerular filtration rate in children with sickle cell disease. Pediatrics, 1950, 5, 127. 
18. Keitel, H. G., Unpublished data.

19. Abel, M. S., and Brown, C. R., Sickle cell disease with severe hematuria simulating renal neoplasm. J. A. M. A., 1948, 136, 624.

20. Sullivan, B. H., Jr., Danger of airplane flight to persons with sicklemia. Ann. Int. Med., 1950, 32, 338.

21. Cooley, J. C., Peterson, W. L., Engel, C. E., and Jernigan, J. P., Clinical triad of massive splenic infarction, sicklemia trait, and high altitude flying. J. A. M. A., 1954, 154, 111.

22. Goodwin, W. E., Alston, E. F., and Semans, J. H., Hematuria and sickle cell disease: Unexplained, gross unilateral, renal hematuria in negroes, coincident with the blood sickling trait. J. Urol., 1950, 63, 79.

23. Singer, K., Robin, S., King, J. C., and Jefferson, R. N., The life span of the sickle cell and the pathogenesis of sickle cell anemia. J. Lab. \& Clin. Med., 1948, 33, 975.

24. Callender, S. T. E., Nickel, J. F., Moore, C. V., and Powell, E. O., Sickle cell disease: Studied by measuring the survival of transfused red blood cells. J. Lab. \& Clin. Med., 1949, 34, 90.

25. Neel, J. V., The inheritance of the sickling phenomenon, with particular reference to sickle cell disease. Blood, 1951, 6, 389.

26. Oliver, J., The Edward Gamaliel Janeway Lecture. The structure of the metabolic process in the nephron. J. Mt. Sinai Hosp., 1948, 15, 175.

27. Finch, C. A., Hegsted, M., Kinney, T. D., Thomas, E. D., Rath, C. E., Haskins, D., Finch, S., and Fluharty, R. G., Iron metabolism. The pathophysiology of iron storage. Blood, 1950, 5, 983.

28. Singer, K., and Singer, L., Studies on abnormal hemoglobins. VIII. The gelling phenomenon of sickle cell hemoglobin: its biologic and diagnostic significance. Blood, 1953, 8, 1008.

29. Ham, T. H., Studies on destruction of red blood cells. I. Chronic hemolytic anemia with paroxysmal nocturnal hemoglobinuria: An investigation of the mechanism of hemolysis, with observations on five cases. Arch. Int. Med., 1939, 64, 1271. 